Article

\title{
Improved Method of Boron Fertilization in Rice (Oryza sativa L.)-Mustard (Brassica juncea L.) Cropping System in Upland Calcareous Soils
}

\author{
Ranjan Laik ${ }^{1}$, Santosh Kumar Singh ${ }^{1}$, Biswajit Pramanick ${ }^{2, *}$, Vandana Kumari ${ }^{1}$, Debabrata Nath ${ }^{1}$ (D), \\ Eldessoky S. Dessoky ${ }^{3}\left(\mathbb{D}\right.$, Attia O. Attia ${ }^{3}$, Mohamed M. Hassan ${ }^{3, *(\mathbb{D})}$ and Akbar Hossain $4, *$ (D) \\ 1 Department of Soil Science, Dr. Rajendra Prasad Central Agricultural University, \\ Samastipur 848125, Bihar, India; rlaik2016@gmail.com (R.L.); santoshraupusa@gmail.com (S.K.S.); \\ singhvandana.guriya@gmail.com (V.K.); nathdeb2@gmail.com (D.N.) \\ 2 Department of Agronomy, Dr. Rajendra Prasad Central Agricultural University, \\ Samastipur 848125, Bihar, India \\ 3 Department of Biology, College of Science, Taif University, P.O. Box 11099, Taif 21944, Saudi Arabia; \\ es.dessouky@tu.edu.sa (E.S.D.); attiaattiaomar@gmail.com (A.O.A.) \\ 4 Department of Agronomy, Bangladesh Wheat and Maize Research Institute, Dinajpur 5200, Bangladesh \\ * Correspondence: biswaji@@rpcau.ac.in (B.P.); m.khyate@tu.edu.sa (M.M.H.); \\ akbarhossainwrc@gmail.com (A.H.)
}

check for updates

Citation: Laik, R.; Singh, S.K.; Pramanick, B.; Kumari, V.; Nath, D.; Dessoky, E.S.; Attia, A.O.;

Hassan, M.M.; Hossain, A. Improved Method of Boron Fertilization in Rice (Oryza sativa L.)-Mustard (Brassica juncea L.) Cropping System in Upland Calcareous Soils. Sustainability 2021 13, 5037. https://doi.org/10.3390/ su13095037

Academic Editor: Thierry Becquer

Received: 24 March 2021

Accepted: 28 April 2021

Published: 30 April 2021

Publisher's Note: MDPI stays neutral with regard to jurisdictional claims in published maps and institutional affiliations.

Copyright: (c) 2021 by the authors. Licensee MDPI, Basel, Switzerland. This article is an open access article distributed under the terms and conditions of the Creative Commons Attribution (CC BY) license (https:/ / creativecommons.org/licenses/by/ $4.0 /)$.
Abstract: Calcareous soils are highly deficient in boron (B) due to having high levels of free $\mathrm{CaCO}_{3}$ and low organic matter. This has become one of the most important deficient micronutrients in Indian soil after zinc ( $\mathrm{Zn}$ ). For various rice (Oryza sativa L.)-based cropping systems, B fertilization is essential for increasing crop productivity and the biofortification of the crop, thus a suitable soil application protocol for B fertilization is required for B-deficient soils. In a six-year experiment, different rates of $B$ application, namely, $0.5,1.0,1.5$, and $2.0 \mathrm{~kg} \mathrm{ha}^{-1} \mathrm{y}^{-1}$, were evaluated to determine the effects of three different modes of B fertilization, i.e., applied only in the first year, applied in alternating years, and applied every year, in a rice (Oryza sativa L.)-Indian mustard (Brassica juncea L.) cropping system. It was observed that the application of B at $1.5 \mathrm{~kg} \mathrm{ha}^{-1}$ every year or $2 \mathrm{~kg} \mathrm{ha}^{-1}$ in alternate years resulted in the highest yield of rice and mustard, as well as the maximum system productivity of the rice-mustard cropping system. Application of $2 \mathrm{~kg} \mathrm{ha}^{-1}$ of B in the initial year showed the maximum B uptake by rice, while application of $1.5-2.0 \mathrm{~kg} \mathrm{ha}^{-1}$ of B every year resulted in the maximum B uptake by the mustard crop. Application of B at $2 \mathrm{~kg} \mathrm{ha}^{-1}$ in alternate years or $1.5 \mathrm{~kg} \mathrm{ha}^{-1}$ every year was the best B-application protocol in B-deficient calcareous soils for ensuring the highest productivity of the rice-mustard cropping system and B availability in the soil.

Keywords: boron fractions; boron fertilization; boron transformation; boron uptake; rice-mustard system

\section{Introduction}

Boron (B) is a limiting factor in crop productivity in rice-based systems [1]. Such a deficiency of boron has emerged as an important micronutrient problem in Indian soils and crops, next to zinc. Analysis reports of soil samples indicate that a deficiency of boron has been found in up to $84 \%$ with a mean of $33 \%$, and upland calcareous areas in India are prone to B deficiency [2]. Various soil factors including $\mathrm{pH}$, organic matter, clay minerals, sesquioxides (Fe and $\mathrm{Al}$ oxides), carbonates, and tillage significantly influence the plant availability to $B$, the content of soil extractable $B$, and different $B$ fractions transformations in soil [3-5]. Retention of B in soil constituents is favoured by an increase in $\mathrm{pH}[6,7]$. Calcareous soils with a light (sandy) texture and a low organic matter content suffer from boron deficiency [8]. An increase in the calcium carbonate content raises soil $\mathrm{pH}$, limiting the availability of $B$ by serving as a sink for B in soil $[9,10]$ where it is involved in the 
surface adsorption of a large portion of the soluble B, thus decreasing its availability for plant uptake [11].

The function of proteins and enzymes are influenced by Boron, and this results in the improvement of membrane integrity [12]. Restricted fruit development and flowering have been observed from having a deficit of $B$. However, the requirement for $B$ varies with the species, crops, and phonological stages of crop growth [12]. There are numerous reports on the positive response of mustard to B fertilization [13-15]. Such a phenomenon strongly indicates a greater degree of sensitivity to B application in the mustard crop. B deficiency in soil decreases rice productivity through an increment in grain sterility, a decrement in the number of productive tillers, less chloroplasts, and a disruption in the grain cooking quality with decreased net assimilate rates $[1,16]$. Authors reported that B fertilization in different rice-based systems resulted in improvements in productivity through a reduction of yield losses, and improvement in the cooking quality of the grain. Thus, the judicial use of B fertilizer is very important. Furthermore, the rice-mustard cropping system is of great importance in eastern India for diversification in the cereal-based rice-wheat cropping system [17] and in making the country self-sufficient in oil production [18].

Boron is found in different components of the soil, including soil solution, organic matter $(\mathrm{OM})$, and minerals. The $\mathrm{B}$ fractionation of soils provides insights into the qualitative and quantitative importance of the fractions of $B$ [19]. Fractionation helps in defining and measuring different types of total soil B, which has the potential to predict the bioavailability, laxity, dynamics, soil processing, and environmental impacts between various chemical types [20,21]. Soil Boron is known to be distributed through geochemical forms, e.g., fine-soluble, oxide bound, specifically adsorbed, organically bound, and residue forms, that have major variations in the bioavailability, mobility, and chemical behaviour of soils and can be transformed under certain conditions. In order to understand its chemistry in soils, the fractionation of B into these types, along with knowledge about the chemistry of $B$, is very important [22]. Boron in soil solution is readily accessible for plant absorption, but the retention of $B$ in soil solution is a crucial feature of plant nutrition and is regulated in other soil fractions by the pools of $B$ and their equilibrium with the soil solution [23]. The positive effects of $B$ applied on successive crops in a growing system can last over varying periods, as B is transformed into different forms in calcareous soil. It is often difficult to estimate the residual effect of the B fertiliser applied at various concentrations for different times in order to make recommendations for B applications for a cropping system. B is generally applied as a soil application at $0.5-1.5 \mathrm{~kg} \mathrm{ha}^{-1}$ during the sowing period of most crops, such as rice, wheat, cotton, and mustard. [24-26]. However, a suitable method of fertilization for a rice-based cropping system in B-deficient calcareous soil has yet to be developed. It is therefore important to be aware of the rate and frequency of $B$ application for the important rice-mustard cropping systems in calcareous soils.

Regarding all of this, a six-year experiment was designed with the objectives: (i) to establish a suitable B-fertilization protocol for a higher yield of rice and mustard; (ii) to study the transformation of $B$ into various extractable fractions; and (iii) to assess the interrelation between readily soluble B with the yield of $\backslash$ crops and the uptake of B.

\section{Materials and Methods}

\subsection{Experimental Site}

A six-year field investigation with a rice-mustard cropping system was conducted at the experimental farm of Dr. Rajendra Prasad, Central Agricultural University, Pusa, Bihar, India $\left(25^{\circ} 94^{\prime} \mathrm{N}, 85^{\circ} 67^{\prime} \mathrm{E}\right.$, and $52 \mathrm{~m}$ above MSL). The field observation was initiated in 2012. The soil of the experimental field is sandy loam soil (typic calciorthent in the soil taxonomy by USDA).

\subsection{Climatic Condition}

The climate of the site comprises mainly three seasons, i.e., rainy (June to September), winter (October to February), and summer (March to May), and mean maximum and 
minimum temperatures on a monthly basis varies between $23.8-36.8^{\circ} \mathrm{C}$ and $9.1-27.2{ }^{\circ} \mathrm{C}$, respectively. Frequent droughts and floods are common and characterized by hot and humid summers and cold winters with an average rainfall of $1200 \mathrm{~mm} \mathrm{y}^{-1}$, most of which occurs from July to September. The soil was potentially B deficient in the upland calcareous areas. The area of each plot was $12 \mathrm{~m}^{2}(4 \mathrm{~m} \times 3 \mathrm{~m})$.

\subsection{Experimental Soils}

The initial characteristics of the experimental site were: surface soil $(0-15 \mathrm{~cm})$ having a $\mathrm{pH}$ of 8.41 (1:2 soil water suspension); electrical conductivity of $0.62 \mathrm{dSm}^{-1}$ (1:2 soil water suspension); free $\mathrm{CaCO}_{3}$ of $34 \%$; organic carbon of $4.23 \mathrm{~g} \mathrm{~kg}^{-1}$; available $\mathrm{N}$ of $188 \mathrm{~kg} \mathrm{ha}^{-1}$; available $\mathrm{P}_{2} \mathrm{O}_{5}$ of $11.3 \mathrm{~kg} \mathrm{ha}^{-1}$; available $\mathrm{K}_{2} \mathrm{O}$ of $88.3 \mathrm{~kg} \mathrm{ha}^{-1}$; and available $\mathrm{S}$ of $11.6 \mathrm{~kg} \mathrm{ha}^{-1}$. The available micronutrients $\mathrm{B}, \mathrm{Zn}, \mathrm{Cu}, \mathrm{Fe}$, and $\mathrm{Mn}$ at the beginning of the experiment were $0.41 \mathrm{mg} \mathrm{kg}^{-1}, 0.66 \mathrm{mg} \mathrm{kg}^{-1}, 2.46 \mathrm{mg} \mathrm{kg}^{-1}, 16.28 \mathrm{mg} \mathrm{kg}^{-1}$, and $4.68 \mathrm{mg} \mathrm{kg}^{-1}$, respectively.

\subsection{Experimental Treatments, Design, and Procedures}

The experiment consisted of three different combinations of Boron (B) application in four rates $\left(0.5,1.0,1.5\right.$, and $\left.2.0 \mathrm{~kg} \mathrm{ha}^{-1}\right)$ in the initial year, alternate year, and every year, with a control plot of $\mathrm{B}$ where no $\mathrm{B}$ was applied. Boron was applied to the soil as Borax $\left(\mathrm{Na}_{2}\left[\mathrm{~B}_{4} \mathrm{O}_{5}(\mathrm{OH})_{4}\right] \cdot 8 \mathrm{H}_{2} \mathrm{O}\right)$ to the rice-mustard cropping system. Different B-fertilization protocols were designed with regard to the previous work performed on the effects of $\mathrm{B}$ fertilization in different crops, such as rice, wheat, cotton, mustard, etc. [24-29]. All treatments were arranged in a randomized complete block design (RCBD) and replicated three times.

During the six years of study, B was applied only once in the initial year applied plot, three times in the alternate years applied plots, and six times in the plots where it was applied every year. Boron was applied before transplanting the rice crop. The present study was undertaken during the sixth year (2017-2018) in both rice and mustard crops. A rice crop of a locally popular variety, Rajendra Bhagwati, was transplanted during late June and was harvested in late October, while the mustard (Rajendra Sufalam variety) was sown in early November and was harvested in late February in each year of the study. A recommended package of practices was followed to grow both of these crops.

The fertilizers, urea at $211 \mathrm{~kg} \mathrm{ha}^{-1}$, diammonium phosphate (DAP) at $130 \mathrm{~kg} \mathrm{ha}^{-1}$, and muriate of potash (MOP) at $100 \mathrm{~kg} \mathrm{ha}^{-1}$, were applied as sources of $\mathrm{N}$, P, and $\mathrm{K}$, respectively, to rice in each experimental plot. For mustard, the rates of urea, DAP, and MOP were $96 \mathrm{~kg} \mathrm{ha}^{-1}, 87 \mathrm{~kg} \mathrm{ha}^{-1}$, and $100 \mathrm{~kg} \mathrm{ha}^{-1}$ in each plot.

\subsection{Extraction Procedures}

\subsubsection{Available B and Extraction of B Fractions in Soil}

Finely ground, 2-mm sieved air-dried soil samples taken from a 0-15 cm depth were used for the extraction of B fractions. The sequential extraction procedure as proposed by $[23,30]$ and modified by Datta et al. [31] was followed to determine the different sequential B fractions in the soil after the mustard harvest, i.e., at the end of the six years of experimentation. A total of five soil samples were taken randomly from each treatment, which was replicated three times to estimate the available B and different B fractions. Thus, a total of 15 samples were there for each treatment. Subsequently, the mean of each treatment was considered from these 15 samples.

\subsubsection{Readily Soluble Fraction (Solution Plus Non-Specifically Adsorbed)}

The supernatant solution was filtered using Whatman No. 42 filter paper, which was aggregated with $5 \mathrm{gm}$ of soil adding $10 \mathrm{~mL}$ of $0.01 \mathrm{M} \mathrm{CaCl}_{2}(1: 2$ soil:solvent) in $50 \mathrm{~mL}$ centrifuges of polyethylene shaken for $16 \mathrm{~h}$ and centrifuged for $30 \mathrm{~min}$ at 10,000 rpm. Clear extracts with azomethine-H were determined in B [32]. 


\subsubsection{Specifically Adsorbed}

The residue from the above step was then extracted with $10 \mathrm{~mL}$ of $0.05 \mathrm{M} \mathrm{KH}_{2} \mathrm{PO}_{4}$ by shaking for $1 \mathrm{~h}$. After centrifugation, B was measured in the clear extract as described in the previous step.

\subsubsection{Oxide Bound}

With $0.2 \mathrm{M} \mathrm{NH}_{4}$-oxalate (1:4 ground:solution) of $20 \mathrm{~mL}$, the residue from the previous step was removed by shaking for $4 \mathrm{~h}$ at a $\mathrm{pH}$ of 3.25. A 14-mL aliquot from the extract was taken into a $50 \mathrm{~mL}$ beaker to remove a slightly yellowish to reddish color due to Fe and the minor dissolution of organic matter colour. The content of the dissolved $\mathrm{Fe}$ as $\mathrm{Fe}(\mathrm{OH})_{3}$ was held on a hot plate and $2 \mathrm{~mL}$ of $5 \mathrm{~N} \mathrm{NaOH}$ solution was applied. After the aliquot in the beaker had been weighed, the weight was decreased by adding distilled water. The suspension was filtered by the filtering substance Whatman No. 42 and the Fe was removed. A 9-mL aliquot was taken from the filtrate and heated on a hotplate at $135 \pm 5{ }^{\circ} \mathrm{C}$ to kill the organic material and added to the $50 \mathrm{~mL}$ Teflon beaker. An amount of $4 \mathrm{~mL}$ concentrated $\mathrm{H}_{2} \mathrm{SO}_{4}$ and $1 \mathrm{~mL} \mathrm{HClO}_{4}(60 \%)$ was applied. Once the volume was decreased to about $6 \mathrm{~mL}$, the $\mathrm{HClO}_{4}$ was additionally applied to the solution by an increase of $0.5 \mathrm{~mL}$. The material was then converted into a polythene tube of $15 \mathrm{~mL}$ and the final volume was $6 \mathrm{~mL}$. B in the clear extract was calculated with a carmine method after centrifugation at $10,000 \mathrm{rpm}$ for $15 \mathrm{~min}$ [32].

\subsubsection{Organically Bound}

The above residue was removed by shaking for $24 \mathrm{~h}$ and then filtering through Whatman No. 42 using $20 \mathrm{~mL}$ of $0.5 \mathrm{M} \mathrm{NaOH}$. The method described by Datta et al. [31] was used to eliminate the color from the filtrate. Carmine [32] determined the B in the simple extract.

\subsubsection{Residual Fraction}

The residue was dried and ground from the previous phase. An amount of $1 \mathrm{~g}$ subsample was taken and put into a $50 \mathrm{~mL}$ Teflon beaker with a small volume of $\mathrm{H}_{2} \mathrm{SO}_{4}, \mathrm{HF}$ of $5 \mathrm{~mL}(40 \%)$, and $\mathrm{HClO}_{4}$ of $0.5 \mathrm{~mL}(60 \%)$ [33]. At $135 \pm 5{ }^{\circ} \mathrm{C}$, the beaker was put on a thermal plate and the amount was reduced to approximately $3 \mathrm{~mL}$. Heating was then applied and we proceeded by adding $5 \mathrm{~mL}$ concentrated $\mathrm{H}_{2} \mathrm{SO}_{4}$ and $5 \mathrm{~mL}$ of $\mathrm{HF}(40 \%)$. In increments of $2-5 \mathrm{~mL}$, additional $\mathrm{HF}$ was applied before the soil was completely digested. Depending on the color intensity in the extract, a clear extract of 3-5 $\mathrm{mL}$ of $\mathrm{HClO}_{4}(60 \%)$ was added after digestion. The heating and removal of $\mathrm{HF}$ und $\mathrm{HClO}_{4}$ reduced the volume to $3-4 \mathrm{~mL}$. The volume was up to $25 \mathrm{~mL}$ and the material moved into centrifuge tubes. The obvious supernatant was determined with carmine after centrifugation of 10,000 rpm B.

\subsection{Analysis of Plant Samples for the Estimation of B Content and Uptake}

During harvest, grain or seed and straw or stover yields for each experimental plot were reported and composite grain/seed and straw/stover samples from each plot were collected. The samples were washed with deionized (DI) water with $0.1 \mathrm{M} \mathrm{HCl}$. Additional moisture was removed. They were placed in new bags of paper and dried at $70{ }^{\circ} \mathrm{C}$ in the oven. Wiley mill ground weight samples were diluted by adding distilled water and the material was filtered through Whatman No. 42 filter papers. The final volume was provided at $50 \mathrm{~mL}$ by a combination of concentrated $\mathrm{HNO}_{3}$ and $\mathrm{HClO}_{4}$ (ratio 9:4).

A $20 \mathrm{~mL}$ B-free tube and a vortexed tube were added with $5 \mathrm{~mL}$ sample aliquot, $2 \mathrm{~mL}$ ammonium acetate buffer ( $\mathrm{pH} 5.5)$, and $2 \mathrm{~mL} 0.02 \mathrm{M}$ EDTA. The tube was once more vortexed and assisted for $1 \mathrm{~h}$ at $25^{\circ} \mathrm{C}$, and vortexed again after $1 \mathrm{~mL}$ azomethine-H reagent had been applied ( $0.9 \%$ azomethine- $\mathrm{H}$ plus $2 \%$ ascorbic acid solution), and the reading was taken at $420 \mathrm{~nm}$ with a spectrophotometer (Systronics 2203) [34]. The current concentration was determined using the standard curve, which consists of the observed $x$-axis boron 
concentration and $y$-axis absorption. The uptake of boron by the rice and mustard crop was estimated as:

$$
\text { Boron uptake }\left(\mathrm{g} \mathrm{ha}^{-1}\right)=\frac{\text { Boron concentration }\left(\frac{\mathrm{mg}}{\mathrm{kg}}\right) \times \operatorname{Dry} \text { matter }\left(\frac{\mathrm{q}}{\mathrm{ha}}\right)}{10}
$$

The rice equivalent yield ( $\mathrm{t} \mathrm{ha}{ }^{-1}$ ) of the rice-mustard system was the average rice yield and rice equivalent yield of mustard. Rice equivalent yield of mustard was determined as follows:

Rice equivalent yield $\left(\mathrm{Mg} \mathrm{ha}^{-1}\right)=\frac{\text { mustard yield }\left(\mathrm{Mg} \mathrm{ha}^{-1}\right) \times \mathrm{MSP} \text { of mustard }\left(\mathrm{INR} \mathrm{kg}^{-1}\right)}{\operatorname{MSP} \text { of rice }\left(\mathrm{INR} \mathrm{kg}^{-1}\right)}$

where, MSP of rice and mustard denotes the minimum support price.

\subsection{Statistical Analysis}

The data were analyzed statistically using the randomized complete block design process [35]. All the data were subjected to the analysis of variance (ANOVA). The interpretation of multiple variance sources by error mean square of the Fisher Snedecor's ' $\mathrm{F}$ ' test at probability level 0.05. For data processing, Windows SPSS 16.0 (SPSS Inc., Chicago, IL, USA) and Microsoft Excel (Microsoft Corp., Pullman, WA, USA) software were used. All the graphs were drawn using Microsoft Excel software (Microsoft Corp., Pullman, WA, USA).

\section{Results}

\subsection{Yields of Rice and Mustard}

Compared to the control, all the B fertilization practices significantly increased the rice grain and straw yields. However, there was no such significant impact of different rates and methods of $B$ application on the grain yield of rice, while the straw yield of rice was significantly varied with the different B-application protocols (Table 1).

Table 1. Rice and mustard yields as influenced by different B-application protocols.

\begin{tabular}{|c|c|c|c|c|}
\hline \multirow{2}{*}{ Treatments } & \multicolumn{2}{|c|}{ Rice Yield (Mg ha ${ }^{-1}$ ) } & \multicolumn{2}{|c|}{ Mustard Yield (Mg ha $\left.{ }^{-1}\right)$} \\
\hline & Grain & Straw & Seed & Stover \\
\hline $\mathrm{T}_{1}$ & $3.94^{\mathrm{a}}$ & $4.73^{\mathrm{d}}$ & $0.95^{\mathrm{fg}}$ & $2.97^{\mathrm{cd}}$ \\
\hline $\mathrm{T}_{2}$ & $3.92^{\mathrm{a}}$ & $4.96^{\mathrm{cd}}$ & $0.87 \mathrm{~g}$ & $3.12^{\mathrm{abcd}}$ \\
\hline $\mathrm{T}_{3}$ & $4.18^{\mathrm{a}}$ & $5.03^{\mathrm{bcd}}$ & $1.00 \mathrm{fg}$ & 3.30 abcd \\
\hline $\mathrm{T}_{4}$ & $4.29^{\mathrm{a}}$ & $5.74^{\mathrm{ab}}$ & $0.96 \mathrm{fg}$ & 3.18 abcd \\
\hline $\mathrm{T}_{5}$ & $4.47^{\mathrm{a}}$ & $5.84^{\mathrm{a}}$ & $1.18^{\text {ef }}$ & $2.99 \mathrm{bcd}$ \\
\hline $\mathrm{T}_{6}$ & $4.28^{\mathrm{a}}$ & $5.02 \mathrm{bcd}$ & $1.37^{\text {de }}$ & $3.26^{\mathrm{abcd}}$ \\
\hline $\mathrm{T}_{7}$ & $4.36^{\mathrm{a}}$ & $5.42 \mathrm{abcd}$ & $1.62 \mathrm{~cd}$ & $3.57^{a b c}$ \\
\hline $\mathrm{T}_{8}$ & $4.45^{\mathrm{a}}$ & 5.35 abcd & $1.84^{\mathrm{abc}}$ & $3.67^{\mathrm{ab}}$ \\
\hline $\mathrm{T}_{9}$ & $4.35^{\mathrm{a}}$ & 5.24 abcd & $1.65^{b}$ & $2.98^{b c d}$ \\
\hline $\mathrm{T}_{10}$ & $4.07^{\mathrm{a}}$ & $4.69^{\mathrm{d}}$ & $1.89^{a b}$ & $3.10^{\mathrm{abcd}}$ \\
\hline $\mathrm{T}_{11}$ & $4.38^{\mathrm{a}}$ & 5.30 abcd & $1.95^{\mathrm{a}}$ & $3.72^{\mathrm{a}}$ \\
\hline $\mathrm{T}_{12}$ & $4.14^{\mathrm{a}}$ & $5.59 \mathrm{abc}$ & $1.64^{b c}$ & $3.38^{\mathrm{abcd}}$ \\
\hline $\mathrm{T}_{13}$ & $3.59^{b}$ & $3.84^{\mathrm{e}}$ & $0.87^{g}$ & $2.84^{\mathrm{d}}$ \\
\hline $\mathrm{LSD}(p \leq 0.05)$ & 0.60 & 0.75 & 0.25 & 0.69 \\
\hline
\end{tabular}

Values followed by different letters in columns are significantly different at $p=0.05$ by LSD. Note: $\mathrm{T}_{1}: 0.5 \mathrm{~kg}_{\mathrm{B}}$ ha ${ }^{-1}$ during the first year; $\mathrm{T}_{2}: 1.0 \mathrm{~kg} \mathrm{~B} \mathrm{ha}{ }^{-1}$ during the first year; $\mathrm{T}_{3}: 1.5 \mathrm{~kg} \mathrm{~B} \mathrm{ha}^{-1}$ during the first year; $\mathrm{T}_{4}: 2.0 \mathrm{~kg} \mathrm{~B}^{-1}$ during the first year; $\mathrm{T}_{5}: 0.5 \mathrm{~kg} \mathrm{~B} \mathrm{ha}{ }^{-1}$ during alternate years; $\mathrm{T}_{6}: 1.0 \mathrm{~kg} \mathrm{~B} \mathrm{ha}^{-1}$ during alternate years; $\mathrm{T}_{7}$ : $1.5 \mathrm{~kg} \mathrm{~B} \mathrm{ha}{ }^{-1}$ during alternate years; $\mathrm{T}_{8}: 2.0 \mathrm{~kg} \mathrm{~B} \mathrm{ha}^{-1}$ during alternate years; $\mathrm{T}_{9}: 0.5 \mathrm{~kg} \mathrm{~B} \mathrm{ha}{ }^{-1}$ every year; $\mathrm{T}_{10}$ : $1.0 \mathrm{~kg} \mathrm{~B} \mathrm{ha}^{-1}$ every year; $\mathrm{T}_{11}: 1.5 \mathrm{~kg} \mathrm{~B} \mathrm{ha}^{-1}$ every year; $\mathrm{T}_{12}: 2.0 \mathrm{~kg} \mathrm{~B} \mathrm{ha}^{-1}$ every year; $\mathrm{T}_{13}$ : control (no-application of B). 
The maximum amount of stover yield of rice was recorded under the application of $B$ at $0.5 \mathrm{~kg} \mathrm{ha}^{-1}$ during alternate years. Application of B at $0.5 \mathrm{~kg} \mathrm{ha}^{-1}$ during alternate years in rice resulted in the improvement in the grain and straw yields to the tune of about $24 \%$ and $51 \%$, respectively, compared to no application of B to this crop. Seed and stover yield of mustard was significantly improved when B was applied at $0.5-2.0 \mathrm{~kg} \mathrm{ha}^{-1}$ in the alternate year or each year. B applied at $1.5 \mathrm{~kg} \mathrm{ha}^{-1}$ each year significantly improved the seed and stover yield of mustard. This treatment resulted in an increment of seed and stover yield to the tune of almost $124 \%$ and $31 \%$, respectively, compared to no application of B. Regarding the system productivity of the rice-mustard cropping system, the application of $B$ at $2.0 \mathrm{~kg} \mathrm{ha}^{-1}$ in the alternate year resulted in the maximum yield, being closely followed by the application of B at $1.5 \mathrm{~kg} \mathrm{ha}^{-1}$ every year (Figure 1 ). Thus, it was found that an increase in the B level and application frequency from $1.5 \mathrm{~kg} \mathrm{ha}^{-1}$ every year to $2 \mathrm{~kg} \mathrm{ha}^{-1}$ every year did not help to improve the system yield.

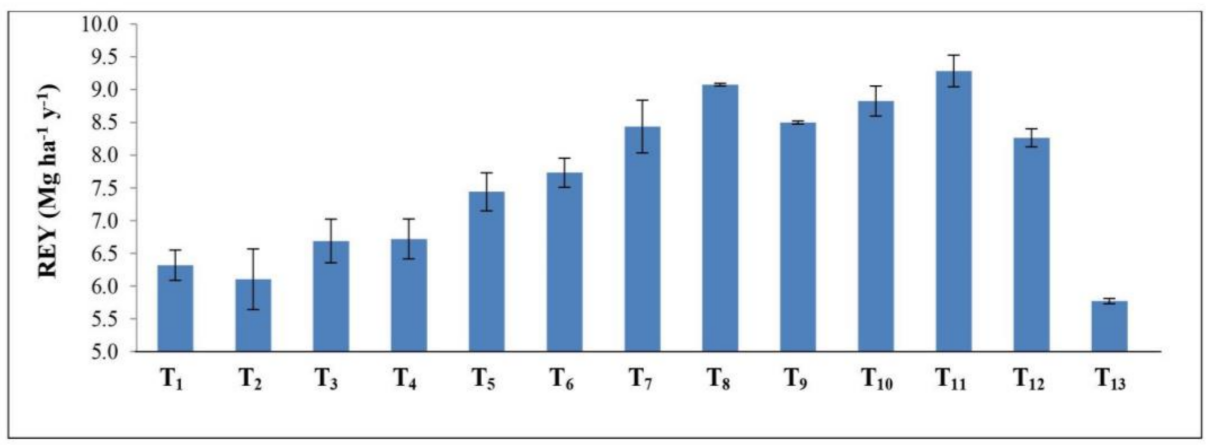

Figure 1. System productivity of the rice-mustard cropping system as influenced by different Bfertilization protocols. Note: Treatment details in Table 1: REY denotes rice equivalent yield; lines above the bar diagram depict the standard deviation $(n=3)$. Values of REY for all treatments in three replications are varied at a $5 \%$ level of probability.

\subsection{Boron Concentration and Uptake}

The $B$ concentration in the rice grain and straw ranged from 11.83 to $23.03 \mathrm{mg} \mathrm{kg}^{-1}$ and 18.73 to $34.59 \mathrm{mg} \mathrm{kg}^{-1}$, respectively, while the B concentration was $13.07-27.20 \mathrm{mg} \mathrm{kg}^{-1}$ in the mustard seed and $24.19-55.24 \mathrm{mg} \mathrm{kg}^{-1}$ in the stover of mustard (Table 2). The maximum amounts of $B$ concentration in both the grain and straw of rice were recorded with the application of $B$ at $2.0 \mathrm{~kg} \mathrm{ha}^{-1}$ every year. A significant improvement in the B content of the rice grain was observed when B was applied every year at $1.0-2.0 \mathrm{~kg} \mathrm{ha}^{-1}$. $B$ applied at $2.0 \mathrm{~kg} \mathrm{ha}^{-1}$ in the first year also showed a significant B concentration in the rice grain. The application of $B$ at $2.0 \mathrm{~kg} \mathrm{ha}^{-1}$ in the first year or every year resulted in the improvement of $\mathrm{B}$ concentration in the rice grain of about $75-78 \%$ compared to no application of $\mathrm{B}$ (control). In the case of B concentration in the mustard seed, the application of $\mathrm{B}$ at $1.5 \mathrm{~kg} \mathrm{ha}^{-1}$ in the first year significantly improved the B concentration compared to other treatments, except for the application of $B$ at $2.0 \mathrm{~kg} \mathrm{ha}^{-1}$ in the first year. On the other hand, the application of B at $2.0 \mathrm{~kg} \mathrm{ha}^{-1}$ every year significantly improved the B content in the stover of mustard. Regarding the B content in the mustard seed, it was observed that the initial application of $B$ at 1.5 or $2.0 \mathrm{~kg} \mathrm{ha}^{-1}$ was better than the other B-application protocols, while the B application at 1.5 or $2.0 \mathrm{~kg} \mathrm{ha}^{-1}$ every year showed a higher B content in the mustard stover than in other B-application protocols.

In several B treatments, the B uptake by rice grain and straw increased significantly compared to no application of B (Table 3). The B uptake by rice grain was much higher when the $B$ application rate was increased i.e., $>1.0 \mathrm{~kg} \mathrm{ha}^{-1}$ in the initial year or alternate years, or every year. However, the application of B at $1.0 \mathrm{~kg} \mathrm{ha}^{-1}$ every year showed a result on par with the application of $B$ at $1.5-2.0 \mathrm{~kg} \mathrm{ha}^{-1}$ during the initial year or alternate years, or every year. Regarding the total B uptake by the rice crop, the best result was estimated with the $B$ application at $2.0 \mathrm{~kg} \mathrm{ha}^{-1}$ in the first year. This treatment showed 
improvement in the B uptake by the crop of about $114 \%$ compared to no B application. All the B-fertilization protocols resulted in a significant improvement in the B uptake by the mustard seed compared to no B application. The highest amount of B uptake by the mustard seed was recorded with the application of B at $1.5 \mathrm{~kg} \mathrm{ha}^{-1}$ every year. B application at $1.5-2.0 \mathrm{~kg} \mathrm{ha}^{-1}$ every year showed a better uptake of B by the mustard crop. Regarding the B uptake by the stover, almost similar trends were recorded. The highest amount of total B uptake by mustard was recorded with the application of B at $2.0 \mathrm{~kg} \mathrm{ha}^{-1}$ every year, and this treatment was narrowly followed by the application of B at $1.5 \mathrm{~kg} \mathrm{ha}^{-1}$ every year. These two treatments showed more than $200 \%$ B uptake by the crop compared to no B application.

Table 2. B concentration in rice and mustard as influenced by different B-application protocols.

\begin{tabular}{|c|c|c|c|c|}
\hline \multirow{3}{*}{ Treatments } & \multicolumn{4}{|c|}{ B Concentration $\left(\mathrm{mg} \mathrm{kg}^{-1}\right)$} \\
\hline & \multicolumn{2}{|c|}{ Rice } & \multicolumn{2}{|c|}{ Mustard } \\
\hline & Grain & Straw & Seed & Stover \\
\hline $\mathrm{T}_{1}$ & $11.83^{g}$ & $18.73^{\mathrm{f}}$ & $17.09^{\mathrm{d}}$ & $29.02^{\mathrm{fg}}$ \\
\hline $\mathrm{T}_{2}$ & $13.17^{\mathrm{fg}}$ & $20.00^{f}$ & $21.27^{\mathrm{c}}$ & $33.32 \mathrm{e}$ \\
\hline $\mathrm{T}_{3}$ & 17.63 de & 25.30 de & $27.20^{\mathrm{a}}$ & $41.48^{c}$ \\
\hline $\mathrm{T}_{4}$ & $22.82^{a b}$ & $29.32^{b c}$ & $25.02^{a b}$ & $47.62^{b}$ \\
\hline $\mathrm{T}_{5}$ & $12.23 \mathrm{~g}$ & $20.24^{\mathrm{f}}$ & $13.07^{f}$ & $24.19^{\mathrm{h}}$ \\
\hline $\mathrm{T}_{6}$ & $15.18^{\text {ef }}$ & $24.17^{\mathrm{e}}$ & $14.38^{\text {ef }}$ & $27.17^{\mathrm{g}}$ \\
\hline $\mathrm{T}_{7}$ & $19.71^{\mathrm{cd}}$ & $28.23^{\mathrm{cd}}$ & $20.97^{c}$ & $36.64^{d}$ \\
\hline $\mathrm{T}_{8}$ & $20.10^{\mathrm{cd}}$ & $30.05^{b c}$ & $20.10^{c}$ & $30.32^{f}$ \\
\hline $\mathrm{T}_{9}$ & $16.33^{\mathrm{e}}$ & $24.24^{\mathrm{e}}$ & $16.46^{\text {de }}$ & $41.02^{c}$ \\
\hline $\mathrm{T}_{10}$ & $20.87^{a b c}$ & $32.80^{a b}$ & $20.08^{c}$ & $47.62^{b}$ \\
\hline $\mathrm{T}_{11}$ & $20.32 \mathrm{bc}$ & $34.29^{a}$ & $21.37^{c}$ & $49.48^{b}$ \\
\hline $\mathrm{T}_{12}$ & $23.03^{\mathrm{a}}$ & $34.59^{a}$ & $24.02^{b}$ & $55.24^{\mathrm{a}}$ \\
\hline $\mathrm{T}_{13}$ & $13.02 \mathrm{fg}$ & $20.20^{\mathrm{f}}$ & $12.17^{\mathrm{f}}$ & $21.30^{i}$ \\
\hline $\operatorname{LSD}(p \leq 0.05)$ & 2.57 & 3.64 & 2.57 & 2.59 \\
\hline
\end{tabular}

Note: Treatment details in Table 1; values followed by different letters in columns are significantly different at $p=0.05$ by LSD.

Table 3. Boron uptake by the rice and mustard crop as influenced by different B-application protocols.

\begin{tabular}{|c|c|c|c|c|c|c|}
\hline \multirow{3}{*}{ Treatments } & \multicolumn{6}{|c|}{ B Uptake (g ha-1) } \\
\hline & \multicolumn{3}{|c|}{ Rice } & \multicolumn{3}{|c|}{ Mustard } \\
\hline & Grain & Straw & Total & Seed & Stover & Total \\
\hline $\mathrm{T}_{1}$ & $46.55^{\mathrm{e}}$ & 88.82 de & 135.37 & $16.36^{\mathrm{e}}$ & 86.52 ef & 102.88 \\
\hline $\mathrm{T}_{2}$ & 52.60 de & 99.87 cde & 152.47 & 18.59 de & $104.61^{\mathrm{d}}$ & 123.21 \\
\hline $\mathrm{T}_{3}$ & $74.65^{b c}$ & $127.92^{b c}$ & 202.57 & $27.12^{\mathrm{c}}$ & $137.73^{b c}$ & 164.85 \\
\hline $\mathrm{T}_{4}$ & $98.77^{a}$ & $168.68^{a}$ & 267.45 & $23.95^{\mathrm{cd}}$ & $152.08^{b}$ & 176.03 \\
\hline $\mathrm{T}_{5}$ & 54.78 de & $98.18^{\text {cde }}$ & 152.96 & 15.57 ef & $73.04^{\mathrm{f}}$ & 88.62 \\
\hline $\mathrm{T}_{6}$ & $65.08^{\text {cde }}$ & $122.10^{b c}$ & 187.18 & $19.85^{\text {de }}$ & 89.08 ef & 108.93 \\
\hline $\mathrm{T}_{7}$ & $86.13^{a b}$ & $125.46^{\mathrm{bc}}$ & 211.59 & $33.96^{\mathrm{b}}$ & $131.01 \mathrm{bcd}$ & 164.96 \\
\hline $\mathrm{T}_{8}$ & $89.38^{a b}$ & $100.88^{\text {cde }}$ & 190.26 & $36.98^{a b}$ & $111.20^{\text {cde }}$ & 148.19 \\
\hline $\mathrm{T}_{9}$ & $70.97^{b c d}$ & 102.97 cde & 173.94 & $27.15^{c}$ & $122.19 \mathrm{bcd}$ & 149.35 \\
\hline $\mathrm{T}_{10}$ & $84.98^{a b}$ & $154.02^{\mathrm{ab}}$ & 239 & $37.90^{\mathrm{ab}}$ & $147.92^{\mathrm{b}}$ & 185.82 \\
\hline $\mathrm{T}_{11}$ & $88.99 \mathrm{ab}$ & $113.09 \mathrm{~cd}$ & 202.08 & $41.65^{\mathrm{a}}$ & $183.86^{\mathrm{a}}$ & 225.52 \\
\hline $\mathrm{T}_{12}$ & $95.28^{a}$ & $124.25^{b c}$ & 219.53 & $39.37^{a b}$ & $186.92^{\mathrm{a}}$ & 226.29 \\
\hline $\mathrm{T}_{13}$ & $46.80^{\mathrm{e}}$ & 77.99 e & 124.79 & $10.51^{\mathrm{f}}$ & $60.71^{\mathrm{f}}$ & 71.22 \\
\hline $\begin{array}{c}\mathrm{LSD}(p \leq \\
0.05)\end{array}$ & 19.84 & 33.53 & - & 6.27 & 30.60 & - \\
\hline
\end{tabular}

Note: Treatment details in Table 1; values followed by different letters in columns are significantly different at $p=0.05$ by LSD. 


\subsection{Boron Fractions}

The evaluation of the fractional soil B distribution showed that the percentage of different fractions to the total B extracted sequentially was, specifically, adsorbed B (4.4-11.9\%), oxide-bound B (10.8-17.0\%), organically bound B (6.2-9.5\%), and residual B (56.1-74.9\%) (Table 4). Most of the B protocols showed significantly higher specifically adsorbed B compared to no B application, except B application at $0.5 \mathrm{~kg} \mathrm{ha}^{-1}$ in the initial year or alternate years. The application of $B$ at $1.5-2.0 \mathrm{~kg} \mathrm{ha}^{-1}$ resulted in the best attainment concerning specifically adsorbed B over all the other B applications. The oxide-bound $\mathrm{B}$ and organically bound B concentrations were improved in all the B-application protocols compared to no B application. However, the variations in these two B fractions were very narrow when the $B$ was applied every year or in alternate years. The range of readily soluble $B$ varied from $0.39 \mathrm{mg} \mathrm{kg}^{-1}$ to $1.92 \mathrm{mg} \mathrm{kg}^{-1}$. The application of $B$ at $2.0 \mathrm{~kg} \mathrm{ha}^{-1}$ every year showed the highest amount of readily soluble $B$, and this treatment was on par with the B application at $1.5 \mathrm{~kg} \mathrm{ha}^{-1}$ every year.

Table 4. Various fractions of B in the soil as influenced by different B-application protocols after 6th year of study.

\begin{tabular}{|c|c|c|c|c|c|c|}
\hline \multirow[b]{2}{*}{ Treatments } & \multicolumn{6}{|c|}{ Sequentially Extracted B Fractions (mg kg $\left.{ }^{-1}\right)$} \\
\hline & Readily Soluble B & $\begin{array}{l}\text { Specifically } \\
\text { Adsorbed B }\end{array}$ & Oxide Bound B & $\begin{array}{c}\text { Organically } \\
\text { Bound B }\end{array}$ & Residual B & Total B \\
\hline $\mathrm{T}_{1}$ & $0.40(2.8)^{g}$ & $0.81(5.6) \mathrm{gh}$ & $2.33(16.1)^{\mathrm{cd}}$ & $1.15(8.0)^{b c}$ & $9.77(67.6)^{b}$ & 14.46 \\
\hline $\mathrm{T}_{2}$ & $0.48(3.0) \mathrm{g}$ & $1.78(11.1)^{\mathrm{e}}$ & $2.37(14.8)^{\mathrm{cd}}$ & $1.18(7.4) b c$ & $10.17(63.6)^{b}$ & 15.98 \\
\hline $\mathrm{T}_{3}$ & $0.51(2.8)^{\mathrm{g}}$ & $1.84(10.1)$ de & $2.48(13.6)^{c}$ & $1.26(6.9)^{b c}$ & $12.20(66.7)^{a b}$ & 18.29 \\
\hline $\mathrm{T}_{4}$ & $0.62(3.3) \mathrm{fg}$ & $1.98(10.5)^{d}$ & $2.53(13.4)^{b c}$ & $1.28(6.8)^{b}$ & $12.50(66.1) a b$ & 18.91 \\
\hline $\mathrm{T}_{5}$ & $0.55(3.2)^{f}$ & $0.87(5.0)^{\mathrm{gh}}$ & $2.82(16.3)$ abc & $1.22(7.1)^{b c}$ & $11.80(68.4){ }^{a b}$ & 17.26 \\
\hline $\mathrm{T}_{6}$ & $0.92(4.3)^{\mathrm{e}}$ & $0.94(4.4) \mathrm{g}$ & $3.22(15.1) \mathrm{abc}$ & $1.43(6.7)^{b}$ & $14.77(69.4)^{\mathrm{a}}$ & 21.28 \\
\hline $\mathrm{T}_{7}$ & $1.23(6.2)^{d}$ & $2.19(11.0)^{c}$ & $2.95(14.8)^{a b c}$ & $1.44(7.2)^{b}$ & $12.10(60.8)^{a b}$ & 19.91 \\
\hline $\mathrm{T}_{8}$ & $1.56(7.5)^{\mathrm{c}}$ & $2.21(10.6)^{c}$ & $3.01(14.5) \mathrm{abc}$ & $1.48(7.1)^{b}$ & $12.56(60.3)^{a b}$ & 20.82 \\
\hline $\mathrm{T}_{9}$ & $0.76(3.7)^{\text {ef }}$ & $1.24(6.1)^{f}$ & $3.47(17.0)^{a b}$ & $1.93(9.5)^{\mathrm{a}}$ & $13.00(63.7)^{a b}$ & 20.40 \\
\hline $\mathrm{T}_{10}$ & $1.63(7.2) b c$ & $2.6(11.5)^{b}$ & $3.56(15.8)^{\mathrm{a}}$ & $2.00(8.9)^{a}$ & $12.80(56.7)^{a b}$ & 22.59 \\
\hline $\mathrm{T}_{11}$ & $1.83(7.8)^{a b}$ & $2.78(11.9)^{\mathrm{a}}$ & $3.59(15.4)^{\mathrm{a}}$ & $2.07(8.9)^{\mathrm{a}}$ & $13.10(56.1)^{\mathrm{ab}}$ & 23.37 \\
\hline $\mathrm{T}_{12}$ & $1.92(8.0)^{\mathrm{a}}$ & $2.81(11.7)^{\mathrm{a}}$ & $3.64(15.2)^{\mathrm{a}}$ & $2.09(8.7)^{\mathrm{a}}$ & $13.46(56.3)^{\mathrm{ab}}$ & 23.92 \\
\hline $\mathrm{T}_{13}$ & $0.39(2.9)^{g}$ & $0.71(5.3)^{h}$ & $1.45(10.8)^{d}$ & $0.83(6.2)^{c}$ & $10.10(74.9)^{b}$ & 13.48 \\
\hline $\operatorname{LSD}(p \leq 0.05)$ & 0.23 & 0.16 & 0.94 & 0.43 & 3.79 & - \\
\hline
\end{tabular}

Note: Treatment details in Table 1; figure in parenthesis indicates the percentage of total; values followed by different letters in columns are significantly different at $p \leq 0.05$ by LSD.

\subsection{Relationship between Readily Soluble B and Grain Yield of Rice and Seed Yield of Mustard}

Readily soluble B was related to both the yield of rice grain as well as the mustard seed and the B uptake by these two crops. Figure $2 \mathrm{a}, \mathrm{b}$ represent the relationship between readily soluble $\mathrm{B}$ and the yields of rice and mustard, respectively. $R^{2}$ values of Figure 2a,b were 0.46 and 0.88 , respectively.

Therefore, a strong relationship between soluble B and mustard yield was evaluated. However, the relationship between rice yield and soluble B was not as high as evaluated in the case of the mustard yield. Such a relationship denoted that the maximum yield level of the rice crop can be attained with up to $2 \mathrm{~kg} \mathrm{ha}^{-1}$ of B application. A further increase in $B$ application will not increase the rice yield. Furthermore, Figure 3a,b represent the relationship between soluble $B$ and the $B$ uptake by rice and mustard, respectively. Here, also, the $R^{2}$ value showed a higher increase in the uptake of $\mathrm{B}$ by mustard than by rice. Thus, a comparatively stronger relationship between soluble B and B uptake by mustard was evaluated than that in the relationship between soluble B and B uptake by rice. 

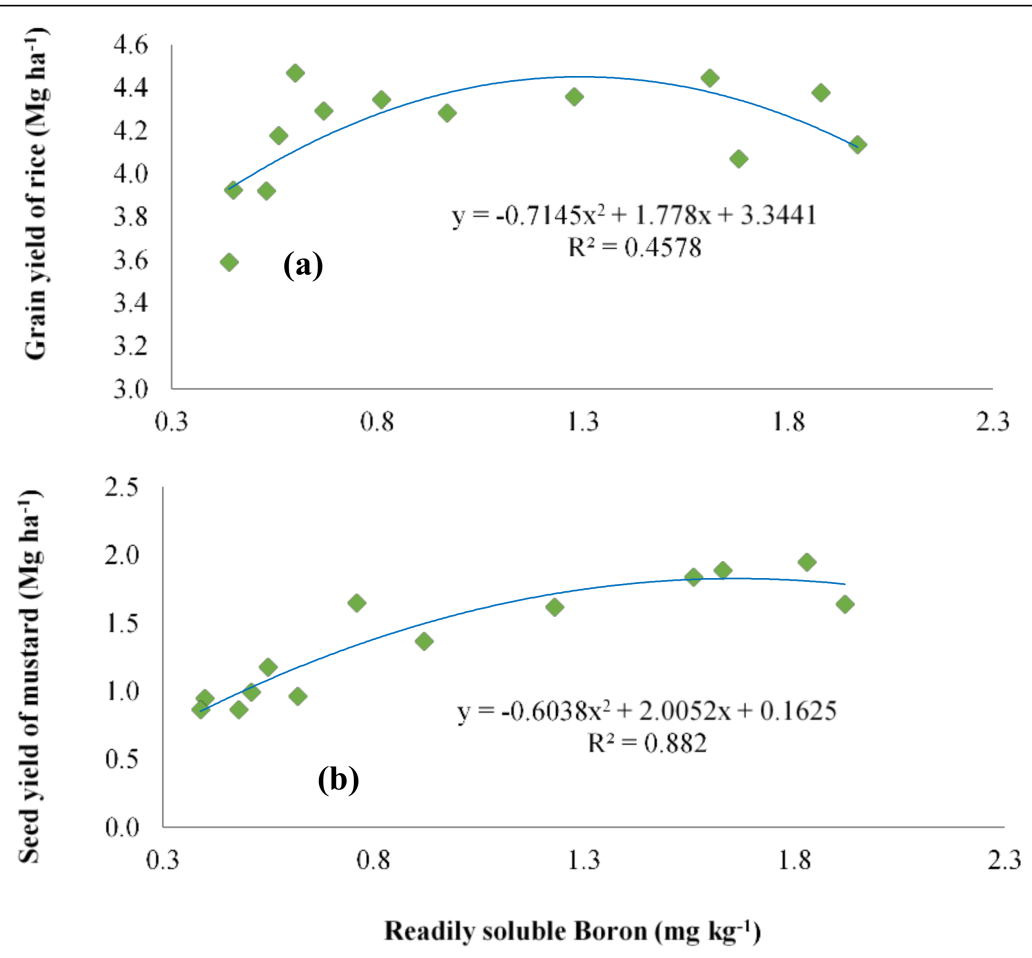

Figure 2. (a) Relationship between soil readily soluble B with grain yield of rice; and (b) seed yield of mustard. Note: Values of readily soluble B and seed yield of mustard are varied at a $5 \%$ level of probability.

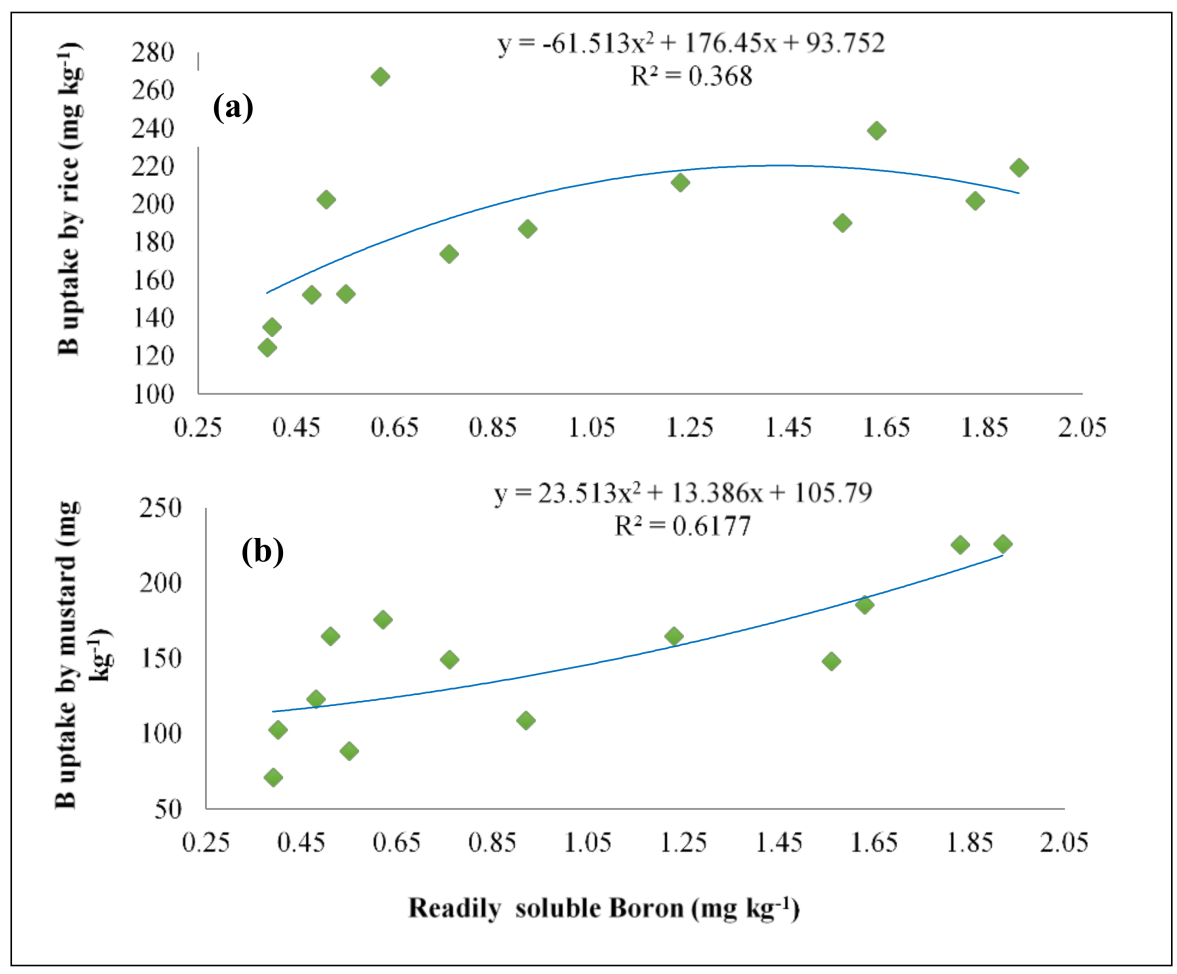

Figure 3. (a) Relationship between readily soluble B and B uptake by rice; and (b) B uptake by mustard. Note: Values of readily soluble B and uptake of B by mustard are varied at a 5\% level of probability. 


\section{Discussion}

Boron deficiency is the second most important micronutrient constraint in soils in India after that of zinc ( $\mathrm{Zn})$. Owing to this acute problem in Indian soil, a considerable yield reduction in many crops was previously reported [36,37]. The availability of boron is mostly related to soil $\mathrm{pH}$ and is widely available at a low $\mathrm{pH}$, but is frequently leached out of acidic sandy soils. Therefore, a deficiency of boron prevails due to the low availability of boron. Calcareous soils with a low organic matter content are more prone to B deficiency [38]. The application of $B$ resulting in increased rice yields might be due to its favorable effect on the cell-dividing metabolic pathways [39]. Khan et al. [27] found that the application of $\mathrm{B}$ at $2 \mathrm{~kg} \mathrm{ha}^{-1}$ to rice, along with the recommended basal doses of N, P, and K fertilizers, resulted in a higher crop yield compared to other B-application protocols. Remesh and Rani [40] reported a significant improvement in the number of spikelets panicle ${ }^{-1}$, grain weight, and the number of filled grains panicle ${ }^{-1}$ through the application of $B$ at $1 \mathrm{~kg}$ $\mathrm{ha}^{-1}$ compared to no application. Katyal and Singh [41] reported a higher B uptake by rice plants with soil-applied $\mathrm{B}$. The authors also reported that less than $40 \%$ of uptaken $\mathrm{B}$ was accumulated in rice grain, and the remaining portion was accumulated in rice straws. Soil application of B at $10 \mathrm{~kg} \mathrm{ha}^{-1}$ enhanced the B content of rice grain [42]. The authors opined that the concentration of $B$ in rice grain and the $B$ uptaken by the grain increased dramatically as B in the soil solution was increased through B application in the soil.

Boron (B) is an important micronutrient that contributes to mustard production and growth [37]. Many studies have shown that yields and yield attributes of the crop, such as the number of silique plants ${ }^{-1}, 1000$ seed weight, etc., were significantly higher with the application of $B[28,29]$. The $B$ fractional data showed that the majority of $B$ fractions, except specifically adsorbed $B$, were improved with the application of $B$ at $1.5-2.0 \mathrm{~kg} \mathrm{ha}^{-1}$ in alternate years or every year. The chances of losses of specifically adsorbed B from the upper soil might be higher compared to other fractions. The supply of specifically adsorbed $\mathrm{B}$ decreased due to the high $\mathrm{pH}$ level of calcareous soils [38]. B might be used during humification to bind to organic matter. In most agricultural land, the B pool is highly correlated with humic colloids [43]. Gürel et al. [44] recorded the development of the B-buffer zone on organic-effect complex, and B-bound fractions leading to B-labile, making it less available for plant uptake. The authors also reported that the majority of $\mathrm{B}$ was present in the residual form (85-88\%), followed by organically bound B $(2.84-4.50 \%)$, adsorbed directly on the colloid soil surfaces $(0.93-1.31 \%)$, oxide-bound B (7.27-8.31\%), and readily soluble $\mathrm{B}$, which was the smallest ranging from $0.40-0.50 \%$ only.

\section{Conclusions}

The current study showed that the application of B at $1.5 \mathrm{~kg} \mathrm{ha}^{-1}$ every year or $2 \mathrm{~kg} \mathrm{ha}^{-1}$ in alternate years resulted in the highest yield of rice and mustard. Hence, the maximum system productivity of the rice-mustard cropping system was also attained under these two B-application protocols. Regarding the B uptake by the crop, an application of $2 \mathrm{~kg} \mathrm{ha}^{-1} \mathrm{~B}$ in the initial year showed the best result, while the application of $1.5-2.0 \mathrm{~kg} \mathrm{ha}^{-1} \mathrm{~B}$ every year resulted in the maximum $\mathrm{B}$ uptake by the mustard crop. This protocol of $B$ application (1.5-2.0 $\mathrm{kg} \mathrm{ha}^{-1} \mathrm{~B}$ every year) also showed the maximum amount of readily soluble $B$. It was also observed that the relationship between readily soluble $B$ and the mustard yield as well as the B uptake by mustard were much stronger than with the rice yield and the $B$ uptake by rice. Therefore, from this experiment, it can be concluded that the application of $B$ at $2 \mathrm{~kg} \mathrm{ha}^{-1}$ in alternate years or $1.5 \mathrm{~kg} \mathrm{ha}^{-1}$ every year was better with regards to the improvement of yield as well as the availability of $B$ in the soil in the rice-mustard cropping system. 
Author Contributions: Conceptualization, R.L., S.K.S., B.P., V.K., and D.N.; methodology, R.L. and S.K.S.; software, R.L., B.P., and A.H.; validation, R.L., S.K.S., B.P., V.K., and D.N.; formal analysis, R.L., B.P., and A.H.; investigation, R.L.; resources, S.K.S. and B.P.; data curation, R.L., B.P., and A.H.; writing-original draft preparation, R.L., S.K.S., B.P., V.K., and D.N.; writing-review and editing, A.H., E.S.D., A.O.A., and M.M.H.; visualization, R.L.; supervision, S.K.S. and B.P.; project administration, S.K.S., B.P., E.S.D., and M.M.H.; funding acquisition, A.H., E.S.D., A.O.A., and M.M.H. All authors have read and agreed to the published version of the manuscript.

Funding: The current work was funded by Dr. Rajendra Prasad Central Agricultural University, Pusa, India and the Taif University Researchers Supporting Project number (TURSP-2020/85), Taif University, Taif, Saudi Arabia. The funding bodies played no role in the study design, data collection, analysis, and interpretation, or the writing of this manuscript.

Informed Consent Statement: Not applicable.

Data Availability Statement: All data recorded and analysis during this study are available in Tables and Figures.

Acknowledgments: All the authors are very much thankful to the Director of Research, Rajendra Prasad Central Agricultural University, Pusa for endowing us with the necessary supports and funds needed for this study. The authors extend their appreciation to Taif University for funding current work by Taif University Researchers Supporting Project number (TURSP-2020/85), Taif University, Taif, Saudi Arabia.

Conflicts of Interest: The authors declare no conflict of interest.

\section{References}

1. Farooq, M.; Rashid, A.; Nadeem, F.; Stuerz, S.; Asch, F.; Bell, R.W.; Siddique, K.H.M. Boron nutrition of rice in different production systems. A review. Agron. Sustain. Dev. 2018, 38, 25. [CrossRef]

2. Singh, M.V. Emerging boron deficiency in soils and crops in India and its management. In Proceedings of the 18th World Congress of Soil Science, Philadelphia, PA, USA, 9-15 July 2006.

3. Jin, J.; Martens, D.C.; Zelazny, L.W. Distributionand plant availability of soil; boron fractions. Soil Sci. Soc. Am. J. 1987, 51, 1228-1231. [CrossRef]

4. Tsalidas, C.D.; Yassoglou, N.; Kosmas, C.S.; Kallianou, C.H. The availability of soil boronfractions to olive trees and barley and their relationshipsto soil properties. Plant Soil. 1994, 162, 211-217.

5. Yermiyahu, U.; Keren, R.; Chen, Y. Boron sorption bysoil in the presence of composted organic matter. Soil Sci. Soc. Am. J. 1995, 59, 405-409. [CrossRef]

6. Mezuman, U.; Karen, R. Boron adsorption by soils using a phenomenological adsorption equation. Soil Sci. Soc. Am. J. 1981, 45, 722-726. [CrossRef]

7. Bloesch, P.M.; Bell, L.C.; Hughes, J.D. Adsorption and desorption of boron by goethite. Aust. J. Soil Res. 1987, 25, 377-390. [CrossRef]

8. Singh, S.P.; Nayyar, V.K. Available boron status of some alluvium-derived arid and semi-arid soils of Punjab. J. Indian Soc. Soil Sci. 1999, 47, 801-802.

9. Shaaban, M.M.; El-Fouly, M.M.; Abdel-Maguid, A.A. Zinc-boron relationship in wheat plants grown under low or high levels of calcium carbonate in the soil. Pak. J. Biol. Sci. 2004, 7, 633-639.

10. Shaaban, M.M.; Abdalla, F.E.; Abou El-Nour, E.A.A.; El-Saady, A.M. Boron/Nitrogen interaction effect ongrowth and yield of faba bean plants grown under sandy soil conditions. Int. J. Agric. Res. 2006, 1, 322-330.

11. Goldberg, S.; Forster, H.S. Boron sorption on calcareous soils and reference calcites. Soil Sci. 1991, 152, 304-309. [CrossRef]

12. Mengel, K.; Kirkby, E.A. Principles of Plant Nutrition; International Potash Institute: Zug, Switzerland, 1987.

13. Islam, M.B. Requirement of Boron for Mustard, Wheatand Chickpea Based Rice Cropping Patterns. Ph.D. Thesis, Department of Soil Science, Bangladesh Agricultural University, Mymensingh, Bangladesh, 2005.

14. Hossain, M.A.; Jahiruddin, M.; Khatun, F. Response of wheat and mustard to manganese, zinc and boron in calcareous soil. Bangladesh J. Crop Sci. 1995, 6, 51-56.

15. Saha, P.K.; Saleque, M.A.; Zaman, S.K.; Bhuiyan, N.J. Response of mustard to S, Zn and B in calcareoussoil. Bangladesh J. Agric. Res. 2003, 28, 633-636.

16. Dunn, D.; Stevens, G.; Kendig, A. Boron fertilization of rice with soil and foliar applications. Crop Manag. 2005, 1, 1-10.

17. Kar, S.; Pramanick, B.; Brahmachari, K.; Saha, G.; Mahapatra, B.S.; Saha, A.; Kumar, A. Exploring the best tillage option in rice based diversified cropping systems in alluvial soil of eastern India. Soil Tillage Res. 2021, 205, 104761. [CrossRef]

18. Singh, S.P.; Mahapatra, B.S.; Pramanick, B.; Yadav, V.R. Effect of irrigation levels, planting methods and mulching on nutrient uptake, yield, quality, water and fertilizer productivity of field mustard (Brassica rapa L.) under sandy loam soil. Agric. Water Manag. 2021, 244, 106539. [CrossRef] 
19. Padbhushan, R.; Kumar, D. Fractions of soil boron: A review. J. Agric. Sci. 2017, 155, 1023-1032. [CrossRef]

20. Hedley, M.J.; Stewart, J.W.B.; Chauhan, B.S. Changes in inorganic and organic soil phosphorus fractionsinduced by cultivation practices and by laboratoryincubations. Soil Sci. Soc. Am. J. 1962, 46, 970-976. [CrossRef]

21. Sui, Y.; Thompson, M.L.; Mize, C.W. Redistributionof biosolids-derived total P applied to a Mollisol. J. Environ. Qual. 1999, 28, 1068-1074. [CrossRef]

22. Hou, J.; Evans, L.J.; Spiers, G.A. Chemical fractionation of soil boron. I. Method development. Can. J. Soil Sci. 1996, 76, 485-491. [CrossRef]

23. Xu, J.M.; Wang, K.; Bell, R.W.; Yang, Y.A.; Huang, L.B. Soil boron fractions and their relationship to soil properties. Soil Sci. Soc. Am. J. 2001, 65, 133-138. [CrossRef]

24. Nadeem, F.; Farooq, M.; Nawaz, A.; Ahmad, R. Boron improves productivity and profitability of bread wheat under zero and plough tillage on alkaline calcareous soil. Field Crop Res. 2019, 239, 1-9. [CrossRef]

25. Kumar, S.; Kumar, D.; Sekhon, K.S.; Choudhary, O.P. Influence of levels and methods of boron application on the yield and uptake of boron by cotton in a calcareous soil of Punjab. Commun. Soil Sci. Plant Anal. 2018, 49, 499-514. [CrossRef]

26. Saleem, M.; Yusop, M.K.; Ishak, F.; Samsuri, A.W.; Hafeez, B. Boron fertilizers borax and colemanite application on rice and their residual effect on the following crop cycle. Soil Sci. Plant Nutr. 2012, 57, 403-410. [CrossRef]

27. Khan, R.; Gurmani, A.H.; Gurmani, A.R.; Sharifzia, M. Effect of boron application on rice yield under wheat rice system. Int. J. Agric. Biol. 2006, 8, 805-808.

28. Bora, P.C.; Hazarika, U. Effect of lime and boron on rainfed toria (Brassica campestris subsp. Oleifera var. Toria). Indian J. Agron. 1997, 42, 361-364.

29. Hossain, M.A.; Jahiruddin, M.; Khatun, F. Response of mustard (Brassica) varieties to boron application. Bangladesh J. Agric. Res. 2012, 37, 137-148. [CrossRef]

30. Hou, J.; Evans, L.J.; Spiers, G.A. Boron fractionation in soils. Commun. Soil Sci. Plant Anal. 1994, 25, 1841-1853. [CrossRef]

31. Datta, S.; Rattan, R.K.; Suribabu, K.; Datta, S.C. Fractionation and colorimetric determination of boron in soils. J. Plant Nutr. Soil Sci. 2002, 165, 23. [CrossRef]

32. Bingham, E. Experimental observations: Introduction. Ann. N. Y. Acad. Sci. 1982, 381, 215. [CrossRef]

33. Lim, C.H.; Jackson, M.L. Dissolution for total elemental analysis. In Methods of Soil Analysis, Part 2, 2nd ed.; Page, A.L., Ed.; Soil Science Society of America, Inc.: Madison, WI, USA, 1994.

34. Wolf, B. The determination of boron in soil extracts, plant materials, composts, manures, water, and nutrient solutions. Commun. Soli Sci. Plant Anal. 1971, 2, 363-374. [CrossRef]

35. Cocharan, W.G.; Cox, G.M. Experimental Designs, 2nd ed.; John Wiley and Sons: New York, NY, USA, 1957 ; p. 611.

36. Sinha, R.B.; Sakal, R.; Singh, A.P.; Bhogal, N.S. Response of some field crops to boron application in calcareous soils. J. Indian Soc. Soil Sci. 1991, 39, 118-122.

37. Masum, M.A.; Miah, M.N.H.; Islam, M.N.; Hossain, M.S.; Mandal, P.; Chowdhury, A.P. Effect of boron fertilization on yield and yield attributes of mustard var. BARI Sarisha-14. J. Biosci. Agric. Res. 2019, 20, 1717-1723. [CrossRef]

38. Nazir, G.; Sharma, U.; Kumar, P. Boron-Its importance in crop production, status in Indian soils and crop responses to its application. Int. J. Adv. Res. 2016, 4, 654-660. [CrossRef]

39. Hatwar, G.P.; Gondane, S.M.; Urkade, S.M.; Ahukar, V. Effect of micronutrients on growth and yield of chilli. J. Soil Crop. 2003, 13, 123-125.

40. Remesh, R.; Rani, B. Effect of boron application through soil and foliar methods on the yield attributes and nutrient uptake of wet land rice. Agric. Update 2017, 12, 301-304. [CrossRef]

41. Katyal, J.C.; Singh, B. Availability of boron in soils and uptake by rice as influenced by moisture regime. J. Agric. Res. 1992, 48, 303-314.

42. Bhutto, M.A.; Maqsood, Z.T.; Arif, S.; Riazuddin; Iqbal, S.; Mahmood, Q.; Akhlaq, A.; Bhutto, R.; Moheyuddin, K.; Mari, A.H.; et al. Effect of zinc and boron fertilizer application on uptake of some micronutrients into grain of rice varieties. J. Agric. Environ. Sci. 2013, 13, 1034-1042.

43. Jones, J.B., Jr. Plant mineral nutrition. In Agronomic Handbook: Management of Crops, Soils and Their Fertility; CRC Pres: Boca Raton, FL, USA, 2003; p. 325.

44. Gürel, S.; Başar, H.; Keskin, E.; Dirim, M.S. The determination of soil boron fractions, their relationships to soil properties and the availability to olive (Olea europea L.) trees. Commun. Soil Sci. Plant Anal. 2019, 50, 1044-1062. [CrossRef] 